\title{
FAKTOR-FAKTOR YANG MEMPENGARUHI LOYALITAS
}

\author{
Yazid \\ Fakutlas Ekonomi Universitas Islam Indonesia
}

\begin{abstract}
Since competition is becoming more and more intense, loyalty is beliefed as the guarantee of the existence of a firm in the long term. Having customer loyalty does not only mean be the owner of a certain level of market share, but also have possession of potential return in the long term. However, loyalty is fragile. Low price, fast moving and better products, and also product availability are among the aspects considered as the sources of switching behavior of the customers Experts say that satisfaction must not be assumed as the end of marketing efforts, but loyalty is. Satisfaction is the mediating variable of quality and loyalty, means that quality is fundamental for a service firm to build customer loyalty or longterm competitive advantage.

Therefore, even for service companies which own loyal customers, it is better for them to cautiously and insistently maintain their customers so that they will not go away to competitors. Since customers' needs and wants are always changing over time, the key aspect to keep customers satisfied is understand well any type of service that the customers really need and want.
\end{abstract}

Keywords: customer satisfaction, customer loyalty, customer delight, elements of loyalty, integrated communication.

\section{PENDAHULUAN}

Kualitas - Kepuasan - Loyalitas merupakan tiga serangkai kata magis yang dibicarakan oleh banyak praktisi dan pakar pemasaran belakangan ini. Urutan kata tersebut tidak bisa dibalik. Kepuasan tidak akan tercipta jika produk atau jasa yang ditawarkan tidak berkualitas. Sementara loyalitas tidak akan terbangun tanpa adanya kepuasan. Meskipun kualitas tidak punya hubungan langsung dengan loyalitas, tetapi pernyataan di atas jelas mengindikasikan bahwa kualitas adalah fundamen dari loyalitas.

Loyalitas, khususnya, menjadi isu sentral bagi dunia bisnis belakangan ini. Loyalitas dianggap sebagai aset yang paling berharga bagi sebuah organisasi, karena dapat mempengaruhi eksistensi organisasi dimasa datang, membuat pelanggan melakukan pembelian ulang, membeli dalam jumlah lebih banyak, serta merekomendasi- kan orang lain untuk membeli, sehingga akhirnya membuat return organisasi dapat dipertahankan atau bahkan meningkat. Namun, dalam kenyataan, membangun loyalitas itu tidak mudah. Ada sejumlah faktor yang mempengaruhinya.

Paper ini ditulis dengan tujuan untuk memaparkan apa itu loyalitas, apa saja faktor-faktor yang mempengaruhinya, serta solusinya. Keseluruhan pembahasan dalam paper ini difokuskan pada loyalitas untuk organisasi jasa

\section{KEPUASAN}

Kepuasan pelanggan merupakan isu penting bagi para manajer pemasaran, khususnya bagi para manajer pamasaran dalam industri jasa. Kepuasan pelanggan sering digunakan sebagai pendekatan untuk loyalitas. Sementara kepuasan sering ditentukan oleh kualitas produk. Kualitas suatu jasa, menurut Lovelock (2005), 
ditentukan oleh interaksi tiga pilar penting, yaitu teknologi, proses, dan orang. Dengan kata lain, membangun loyalitas pelanggan ternyata dimulai dari pabrik (Durkin, 2005), perlu melibatkan banyak pihak atau faktor internal maupun eksternal organisasi.

Kita melihat bahwa upaya memuaskan pelanggan itu sering dianggap sebagai tujuan akhir, sebagaimana terbukti pada survey-survey terdahulu yang menekankan kepuasan. Mestinya, selain kepuasan, tujuan pemasaran adalah juga untuk menciptakan awareness, membangun image/persepsi dan loyalitas (Rebekah dan Sharyn, 2004). Kepuasan adalah perbandingan antara pengalaman setelah dan sebelum pembelian, atau dengan harapan (ideal), atau dengan persepsi yang dimiliki konsumen terhadap kinerja suatu produk (Skogland et al, 2004). Statemen ini didasarkan pada disconfirmation theory ${ }^{l}$ yang merupakan postulate kepuasan. Dari postulate ini muncul tiga kemungkinan:

a. Konfirmasi muncul bila kinerja aktual sesuai dengan standar yang ditetapkan konsumen, yang akan mengarahkan pada perasaan netral.

b. Diskonfirmasi positif muncul bila kinerja melebihi standar (harapan atau ideal) yang dimiliki konsumen, yang akan mengarahkan kepada kepuasan bahkan delighted

c. Diskonfirmasi negatif muncul bila kinerja dibawah standar (harapan atau ideal) yang dimiliki konsumen, yang akan mengarahkan kepada ketidakpuasan

${ }^{1}$ Disconfirmation theory menyatakan bahwa mengkonfirmasi harapan ideal konsumen dengan kinerja aktual suatu produk itu sangat sulit (kalau tidak boleh dikatakan mustahil), oleh karena itu teori ini memaparkan bahwa konsumen mau mengubah harapan idealnya dan menerima bahwa kinerja barang atau jasa yang diingininya itu, ternyata, tidak sama dengan atau kurang dari harapan idealnya, namun ketidaksamaan harapan dan kinerja produk (diskonfirmasi) dimaksud pada level tertentu, diterima dan sudah membuatnya puas.
Kepuasan adalah respon emosional post consumption yang mungkin muncul sebagai hasil dari membandingkan kinerja yang diharapkan dengan kinerja aktual suatu produk (Lovelock et al, 2002). Pendapat yang berbeda, menyatakan bahwa mungkin saja kepuasan akan muncul meski tanpa upaya perbandingan antara harapan dengan kinerja (Oliver, 1996). Pendapat ini sejalan dengan hasil studi Patterson (1997) pada riset-riset terdahulu yang mengungkapkan bahwa kepuasan tidak selalu memiliki anteseden diskonfirmasi. Menurut Oliver (1989), jika kepuasan itu sendiri adalah bentuk respon emosional, maka ateseden (jika ada) dan pendorong kepuasan bisa saja emosional atau kognitif, tergantung situasi yang melingkupinya.

Disamping market share dan kinerja keuangan, kepuasan konsumen dianggap sebagai ukuran keberhasilan kinerja bisnis. Yang perlu dipahami adalah bahwa nilai sejati pengukuran kepuasan bukan terletak pada penentuan seberapa puas konsumen, akan tetapi pada apa yang perlu dilakukan untuk memperbaiki pengalaman pelanggan. Karena itu, tantangan sebenarya dari strategi organisasi yang komit terhadap pelanggan adalah bagaimana memfokuskan proses perbaikan dan inovasi sehingga mampu mengelola kepuasan pelanggan dengan baik (Mendelsohn, 1998). Masih menurut Mendelsohn (1998), akar dari pengukuran kepuasan pelanggan terdiri dari dua ide yang sudah diterima secara umum. Pertama, biaya mempertahankan pelanggan yang ada itu lebih murah daripada merekrut pelanggan baru. Memuaskan untuk tujuan mempertahankan pelanggan adalah strategi yang brilian baik untuk organisasi yang frequency-dependent maupun referraldependent. Dari sisi frekuensi, nilai pembelian berulang dan informasi jangka panjang adalah signifikan. Bila organisasi bergantung kepada referal (getok-tular, pen), 
pelanggan yang puas adalah cara paling baik untuk mendapatkan pelanggan baru. Kedua, meningkatnya persaingan dalam bentuk produk, organisasi dan gerai distribusi akan meningkatkan godaan kepada pelanggan untuk pindah. Karena itu memuaskan pelanggan adalah strategi yang tepat, bukan saja untuk mempertahankan market share dari serangan pesaing, tetapi juga untuk mendorong pembelian ulang atau pembelian produk lain yang ditawarkan organisasi.

\section{LOYALITAS}

Loyalitas pelanggan adalah salah satu konsep inti dari paradigma relationship marketing (Dwyer, Schurr, and Oh, 1987; Wetzer, de Ruyter, and Lemmick, 2000). Wabster's mendefinisikan loyalitas sebagai "unswering allegiance", "setia atau komit terhadap seseorang kepada siapa kesetiaan diberikan" atau "setia kepada negara, suatu sebab, ideal, atau adat kebiasaan". Durkin (2005) menyatakan bahwa loyalitas adalah fungsi dari tindakan dan sikap. Sikap yang merefleksikan keinginan untuk mempertahankan hubungan yang bermakna (Moorman, Zaltman, and Deshpande, 1992). Dalam konteks bisnis, Lovelock et al (2005), menggambarkan bahwa loyalitas pelanggan sebagai kemauan pelanggan untuk berpatron dengan suatu perusahaan dalam jangka panjang, dan merekomendasikan produk-produk perusahaan kepada teman atau orang lain. Sementara loyalitas terhadap merek mencakup kerpilakuan yang luas termasuk preferensi, kesukaan, dan minat dimasa datang. Sementara menurut Dwyer et al. (1987: 19) loyalitas adalah "suatu janji eksplisit atau implisit untuk terus menerus menjalin hubungan antar partner pertukaran" atau menurut Gruen et al (2000, 37) suatu "ikatan psikologis" dengan suatu organisasi meski salah satu pihak dari hubungan per-partner-an itu pernah mengecewakannya. Jadi loyalitas itu dapat juga dikatakan sebagai komitmen ter- hadap sesuatu (negara, organisasi, produk atau merek, agama, adat-istiadat, orang, partner, dan sebagainya).

Jika dilihat dari perilakunya, motivasi pelanggan untuk loyal terhadap suatu merek dapat didasarkan pada alasan:

a. Secara keperilakuan para pelanggan loyal karena mereka memiliki dedikasi kepada merek tertentu (loyalitas atitudinal atau loyalitas aktif). Struktur preferensi mereka memperlihatkan utilitas yang sangat tinggi terhadap suatu merek tertentu dan sangat rendah terhadap merek yang lain, atau

b. Karena merek tersebut memiliki atribut berupa value kinerja yang tidak bisa disamai oleh merek lain (loyalitas kinerja), atau

c. Hanya karena kemudahan mendapatkan merek tersebut seperti yang sudahsudah (loyalitas kenyamanan). Loyalitas ini hampir terjadi pada semua kategori barang atau jasa. Para pelanggan tidak memerlukan waktu dan tenaga untuk melakukan evaluasi kognitif untuk membandingkan alternatif-alternatif yang ada pada setiap kali kesempatan pembelian. Mereka cenderung loyal kepada merek yang mereka pakai selama merek dari suatu kategori tertentu tersebut mampu memenuhi kebutuhan dasar mereka. Jenis loyalitas ini paling rapuh, karena sekali mereka kecewa dengan merek yang mereka pakai sudah cukup menjadi alasan bagi mereka untuk pindah ke merek lain, atau

d. Bahkan karena pelanggan tidak memiliki pilihan (loyalitas karena tidak ada pilihan lain).

Dari paparan di atas dapat ditarik pengertian bahwa loyalitas berkaitan dengan perilaku-perilaku pelanggan yang diinginkan organisasi, seperti meningkatnya pembelian ulang, periklanan getok-tular yang lebih 
positif dan berkurangnya perpindahan pelanggan ke pesaing. Loyalitas dapat juga disebut sebagai komitmen terhadap sesuatu atau seseorang. Loyalitas merujuk kepada perasaan, atau ikatan emosional, yang membuat seseorang mau mengikatkan diri dengan suatu organisasi atau merek, meskipun ia bisa saja memperoleh produk yang lebih baik dari pesaing atau meski organisasi -kepada siapa loyalitas diberikan- pernah melakukan sesuatu yang menyakitkan. Karena itu, para pemasar atau organisasi perlu melakukan upaya-upaya agar konsumen berperilaku atau melakukan tindakan yang diinginkan sebab perilaku atau tindakan tersebut menguntungkan.

\section{FONDASI DARI LOYALITAS PELANGGAN DAN HAMBATAN UNTUK PINDAH}

Fondasi loyalitas adalah kepuasan. Pelanggan yang loyal hampir pasti adalah pelanggan yang puas, sebaliknya, pelanggan yang puas belum tentu loyal. Pelanggan yang puas atau bahkan delighted lebih mungkin akan menjadi pelanggan yang loyal terhadap perusahaan atau merek, hanya melakukan pembelian dengan satu supplier, dan menyebarkan getok-tular yang positif. Sementara itu, ketidakpuasan akan mendorong pelanggan pergi dan juga merupakan faktor kunci perilaku switching, apalagi jika ada produk yang lebih baik, lebih cepat, dan lebih murah, maka loyalitas pelanggan bisa berkurang atau bahkan hilang.

Menurut Lovelock et al. (2005), jika dikaitkan dengan definisi kepuasan di atas, maka hubungan kepuasan dan loyalitas dapat dibagi kedalam tiga zona. Pertama adalah zone of defection yang menunjukkan level kepuasan yang rendah. Pelanggan akan pindah kecuali bila biaya perpindahannya itu tinggi atau tidak ada alternatif yang sepadan atau yang mudah didapat. Pelanggan yang benar-benar tidak puas dapat berubah menjadi "teroris", yang menyebarkan getok- tular negatif. Kedua, zone of indifference yang menunjukkan level kepuasan sedang. Pada level ini pelanggan akan pindah bila mereka menemukan alternatif yang lebih baik. Ketiga, adalah zone of affection yang menunjukkan level kepuasan yang tinggi, dan pelanggan dapat memiliki loyalitas atitudinal yang tinggi dan menyebabkan pelanggan tidak berminat pindah ke pemberi jasa alternatif.

Jadi, kalau perusahaan tidak menginginkan pelanggannya pindah ke pesaing, berilah pelanggan kepuasan yang tinggi. Lovelok et al, (2001) menemukan banyak literatur pemasaran yang menyebutkan bahwa upaya memuaskan pelanggan diarahkan untuk membentuk loyalitas atitudinal. Bansal et al (2004) menyatakan bahwa loyalitas atitudinal sebenarnya sama saja dengan loyalitas keperilakuan. Oliver (1980); Patterson, (1997); Bolton, (1998), Page and Eddy, (1999); Jones and Suh, (2000) menyatakan bahwa loyalitas atitudinal adalah hasil dari kepuasan yang tinggi.

Karena permintaan konsumen selalu berubah dengan tuntutan yang semakin meningkat, maka pelaksanaan proses dan penyajian, untuk jasa apa pun, perlu didasari oleh semangat perubahan atau perbaikan yang tiada henti. Untuk bisa memperbaiki proses dan penyajian, manajemen harus bisa menjawab secara jelas tiga pertanyaan strategis berikut:

a. Seberapa puaskah para pelanggan terhadap jasa kita?

b. Apa yang bisa dilakukan terhadap proses dan penyajian yang sekarang untuk meningkatkan kepuasan pelanggan? dan

c. Proses dan penyajian (baru yang berbeda atau unik) macam apa yang diperlukan untuk mempertahankan atau meningkatkan kepuasan pelanggan?

Jawaban yang jelas dan fokus dari tiga pertanyaan tersebut sangat penting artinya karena dapat dijadikan dasar untuk 
menyusun strategi kompetitif organisasi yang berbasis pada proses operasi dan penyajian jasa.

Hal yang perlu diperhatikan oleh para manajer, sekali lagi, ialah bahwa meski level kepuasan konsumen sudah sangat tinggi, namun itu tidak otomatis membuat konsumen loyal. Beberapa aspek yang diyakini dapat menurunkan tingkat loyalitas adalah, antara lain, pertama, makin banyaknya produk (barang atau jasa) yang hadir di pasar (pasar menjadi semakin sempit) yang menawarkan benefit yang hampir tidak bisa dibedakan satu sama lain secara signifikan. Kedua, perkembangan teknologi yang demikian cepat dan semakin canggih, disisi yang lain, telah memungkinkan proses produksi kian efisien, sehingga produk atau jasa dapat dijual dengan harga murah, telah membuat intensitas tantangan untuk membangun loyalitas menjadi kian meningkat. Sejumlah riset mengungkapkan bahwa dalam diri tiap pelanggan yang sudah dipuaskan sekalipun, masih tetap ada kemungkinan bahwa pada suatu titik waktu tertentu nanti pelanggan akan pindah untuk membeli produk yang kinerjanya lebih baik.

Dengan plus-minus potensi seperti tersebut di atas, kepuasan konsumen telah lama digunakan sebagai proxy untuk keberhasilan organisasi diatas asumsi bahwa kepuasan memiliki hubungan yang erat dengan loyalitas dan retention (Patterson, 2004). Para periset mengingatkan pentingnya mempertahankan pelanggan melalui kepuasan dan kualitas, karena mereka melihat bukti bahwa biaya mempertahankan pelanggan makin lama makin turun sebagai hasil dari efek pembelajaran dan berkurangnya ongkos kegagalan pelayanan, meningkatkan patronage; sementara secara simultan pelanggan membeli lebih banyak, memiliki jumlah keluhan yang semakin berkurang dan/atau sejumlah perilaku menguntungkan lainnya, termasuk mau membayar harga lebih tinggi (Skogland, 2004), mau me- rekomendasikan lewat getok-tular kepada konsumen lain, dan mencegah berpindahnya pelanggan ke pesaing, serta memungkinkan organisasi memiliki keunggulan kompetitif (Lovelock et al, 2005).

Seperti sudah dipaparkan di atas, semakin banyaknya jasa di pasar dengan feature tawaran yang sulit dibedakan satu sama lain telah membuat pelanggan memiliki banyak pilihan yang boleh dikatakan setara sehingga merentankan loyalitas pelanggan. Kehadiran jasa lain tersebut telah mengurangi resiko perpindahan dari jasa yang satu ke jasa yang lain. Dengan kata lain, intensitas persaingan seperti sekarang ini telah menghadirkan problem mempertahankan pelanggan atau loyalitas. Untuk mengatasi persoalan ini, banyak yang berpendapat bahwa organisasi harus mampu membuat customer delight (memberi lebih dari yang diharapkan pelanggan) setiap waktu. Mereka yakin bahwa customer delight merupakan peristiwa mengesankan yang akan selalu diingat oleh setiap pelanggan.

\section{PERLUNYA SIKAP HATI-HATI TERHADAP KONSEP CUSTOMER DELIGHT!}

Sepintas, konsep customer delight terlihat sangat menjanjikan. Namun demikian, para produsen. Selalu membuat customer delight, pada awalnya terlihat sebagai taktik yang brilian, namum sedikit penalaran sudah cukup memperlihatkan bahwa selalu membuat customer delight setiap saat adalah strategi yang absurd (Gurney, 1999). Sebab, bila organisasi selalu melakukannya akan menghasilkan harapan pelanggan yang semakin meningkat. Dengan harapan yang selalu meningkat, berarti organisasi dituntut untuk senantiasa mampu menawarkan produk yang kinerjanya selalu meningkat pula agar tetap bisa memberi pelayanan yang mengesankan tersebut. Karena kemampuan kreasi kita terbatas, 
upaya untuk senantiasa membuat customer delight, pada akhirnya akan menghadapkan karyawan pada pertanyaan: "Apalagi yang bisa kami lakukan untuk meningkatkan pengalaman para pelanggan?"

Menurut Gurney (1999), para pelanggan sebenarnya tidak menginginkan delighted setiap saat, karena hal itu justru dapat membosankan. Sebab, setiap minggu konsumen menerima puluhan kali layanan dari berbagai organisasi, dan kebanyakan interaksi layanan tersebut bersifat rutin. Keinginan standar para pelanggan pada setiap kali kesempatan interaksi adalah kemampuan kerja para karyawan yang efisien, kemauan tulus untuk menolong dan berperilaku menyenangkan. Kinerja para karyawan adalah sentral perhatian para pelanggan bukannya interaksi pelayanan itu sendiri. Dengan kata lain, kinerja karyawanlah yang diperhatikan para pelanggan.

Kunci penting untuk menghasilkan customer delight bukan pada kelebihan kinerja di atas harapan, tapi pada kesempatan. Sementara kebanyakan pelayanan bersifat rutin, dalam suatu rentang waktu tertentu situasi luar biasa akan muncul dengan sendirinya, yang pemicunya bisa berupa karena adanya keluhan, pertanyaan, permintaan khusus, atau sesuatu yang membuat karyawan harus "pergi" (mengantarkan sesuatu atau bertindak) lebih jauh. Kunci untuk mengatasi situasi-situasi luar biasa seperti ini adalah skill dan pemberdayaan. Apabila para karyawan telah dilatih untuk melihat kesempatan-kesempatan seperti itu dan diberdayakan untuk melakukan tindakan yang tepat atas inisiatif mereka sendiri ketika suatu situasi luar biasa tersebut muncul, para pelanggan akan delighted pada saat yang tepat. Delighted tidak akan muncul bila para pelanggan memperolehnya setiap saat mereka melakukan transaksi atau interaksi dengan organisasi.

\section{UNSUR-UNSUR LOYALITAS}

Untuk memiliki konsumen yang loyal, para produsen perlu terlebih dahulu memahami, paling tidak, empat unsur loyalitas yang terdiri dari customer value, consumer characteristics, switching barrier, dan customer satisfaction, (Budi, 2006).

a. Customer value menyangkut persepsi konsumen terhadap hasil kalkulasi cost and benefit yang akan diperoleh dari suatu merek untuk produk yang akan dibelinya. Jika, menurut persepsi konsumen, benefit suatu merek dibanding merek pesaing lebih besar daripada cost-nya, maka disebut customer value. Konsumen akan memilih merek atau produk yang menurut persepsinya menawarkan benefit terbesar. Pemahaman terhadap value yang dianut konsumen akan membuat organisasi memiliki salah satu sumber potensial untuk membangun keunggulan kompetitif yang akan membuat pelanggannya loyal.

b. Consumer characteristics berkaitan dengan latar belakang budaya dan pengalaman konsumen yang mempengaruhi karakter individual konsumen. Latar belakang yang berbeda akan membentuk karakteristik individual yang berbeda pula. Selanjutnya, perbedaan tersebut membuat nilai dan keyakinan yang dianut seorang konsumen berbeda antara satu dengan lainnya. Karena itu, pemahaman terhadap perbedaan karakter ini akan membuat produsen bisa mendeteksi mana atau siapa konsumen yang pada dasarnya memang loyalis dan mana konsumen yang oportunis, yang suka berpindah dari satu supplier ke yang lain, dengan tanpa mempedulikan kebutuhan, manfaat lebih, ataupun resiko yang akan diterimanya. Pada akhirnya, kemampuan identifikasi ini akan membuat 
organisasi lebih fokus dalam menjalankan program loyalitasnya.

c. Switching barrier adalah hambatan yang dibangun untuk mencegah konsumen berpindah ke merek yang lain. Hambatan tersebut dapat bersifat ekonomis, sosial, psikologis, fungsional, dan ritual atau kebiasaan yang dilakukan. Biasanya, seorang konsumen akan memilih melanggar barrier tersebut dan mau menerima resiko apapun seperti tersebut di atas, ketika mendapati bahwa produk dengan merek yang diingininya tidak tersedia pada saat dibutuhkan. Switching barrier hendaknya unik, sulit ditiru oleh yang lain. Untuk organisasi jasa, skill karyawan merupakan salah satu potensi yang sulit ditiru dalam mencegah perpindahan pelanggan ke pesaing.

d. Customer satisfaction menjelaskan bahwa konsumen yang puas belum tentu loyal, sebaliknya, konsumen yang loyal sudah tentu konsumen yang puas. Kepuasan akan mendorong pembelian ulang. Dengan demikian, kepuasan merupakan faktor penting loyalitas seorang pelanggan. Pernyataan di muka tidak dimaksudkan untuk menjelaskan bahwa kepuasan adalah satu-satunya penentu loyalitas pelanggan. Juga tidak dimaksudkan bahwa pembelian ulang adalah ukuran yang akurat untuk kesetiaan pelanggan. Karena, bisa jadi, seorang konsumen membeli suatu produk secara berulang meski produk tersebut tidak memuaskannya. Ia membeli dan membeli lagi karena tidak atau belum ada pilihan lain yang lebih baik baginya.

Pengetahuan dan kemampuan organisasi mentransformasi keempat unsur loyalitas tersebut di atas kedalam produk yang ditawarkannya kepada para pelanggan, kiranya, merupakan sumber keunggulan kompetitif yang akan menghasilkan loyalitas pelanggan. Selanjutnya, agar keunggulan kompetitif tersebut bisa direaslisasikan, organisasi jasa perlu menerapkan sejumlah strategi, antara lain: value dan quality function deployment (Sher, 2006), memiliki komitmen terhadap pelanggan (Fullerton, 2003; Cheng, 2006)), orientasi kepada karyawan (Hennig-Thurou, 2004), garansi jasa (Fabien, 2005), dan komunikasi terintegrasi (Grove, et al. 2002).

\section{Value dan Quality Function Deployment (QFD)}

Value adalah jumlah dari semua bagian dari suatu keputusan pembelian suatu produk dibanding dengan produk yang lain (customers value). Definisi lain merumuskan value sebagai jumlah uang atau pengorbanan lain yang diberikan untuk memperoleh suatu barang atau jasa. Gary Heil et $\mathrm{al}^{2}$, merumuskan value sebagai: “... persamaan yang menyeimbangkan antara produk dan kualitas pelayanan dengan reliabilitas, waktu penyajian, respon keseluruhan, dan harga..." Apapun rumusannya, kita semua tahu dan meyakini bahwa bila suatu organisasi secara konsisten menciptakan dan menyampaikan value terbaik akan memenangkan persaingan, merebut simpati konsumen, memeproleh uang, dan market share.

Tantangan yang harus dihadapi dunia bisnis sekarang adalah menciptakan keunggulan kompetitif melalui perbaikan yang terus menerus sehingga senantiasa mampu menyampaikan customers value, mengantisipasi atau mempengaruhi arah persaingan, pasar, dan industri dimasa datang. Sementara itu, kata value itu sendiri dimaknai secara berbeda oleh setiap individu, termasuk perbedaan pengertian yang dimiliki konsumen dan produsen. Oleh karena itu, tugas produsen adalah mema-

\footnotetext{
${ }^{2}$ Dikutip dari Mariotti, (1997)
} 
hami dengan baik value yang dimiliki konsumen targetnya untuk dipadukan dengan value yang dimilikinya sehingga mampu menghasilkan produk yang memiliki shared value.

Untuk itu Sher (2006) mengusulkan kepada organisasi agar menggunakan QFD. QFD adalah proses yang komplit yang menggunakan metode sistematik untuk menterjemahkan suara/value pelanggan kedalam design, komponen, proses, cara penyajian, dan biaya produk (proses dan cara penyajian tersebut). QFD memungkin kan organisasi untuk fokus kepada kebutuhan atau value pelanggan sebagai dasar dalam pembuatan perencanaa produk. Sebagai tambahan, QFD adalah design yang dibuat lebih dahulu, kemudian membuat barang atau jasa yang menarik, yang konsumen mau membelinya (secara berulang). Karena itu, ketika barang atau jasa itu berada pada tahap perencanaan, semua bagian yang relevan, termasuk pemasaran, karyawan dan konsumen, design, engineering, manufacturing dan quality certification, harus bersatu padu bekerja sama agar rencana dimaksud dapat direalisasikan dengan baik.

\section{Komitmen terhadap Pelanggan}

Komitmen kepada pelanggan sekarang ini dipandang sebagai variabel kunci dalam pemasaran berdasarkan hubungan. Komitmen terhadap pelanggan bisa didasarkan atas shared values dan identifikasi atau berdasarkan ongkos perpindahan dan ketergantungan. Dari riset Fullerton (2003) terungkap bahwa ketika komitmen kepada pelanggan didasarkan atas shared values (afektif) dan identifikasi, komitmen tersebut memiliki dampak positif pada loyalitas pelanggan. Namun, bila komitmen tersebut didasarkan atas ongkos perpindahan dan ketergantungan, efek komitmen terhadap pelanggan menjadi kurang jelas.

Dalam risetnya itu Fullerton menemukan bahwa, jika kedua jenis komitmen itu digunakan secara bersama-sama, ada interaksi yang signifikan antara kedua jenis komitmen tersebut terhadap kesetiaan pelanggan. Karena itu kedua jenis komitmen tersebut perlu dipahami secara baik agar kesetiaan pelanggan dapat dibangun secara efektif. Lain dari itu, pemahaman terhadap komitmen memungkinkan manajemen juga mampu mengidentifikasi komitmen mana yang akan membuat pelanggan mau membayar lebih untuk jasa yang diinginkannya.

Shared values adalah upaya organisasi untuk mempertemukan value pelanggan dengan value organisasi sehingga dapat menghasilkan produk atau jasa yang tepat, untuk pelanggan yang tepat dan pada saat/situasi yang tepat. Seperti sudah disampaikan di atas, setiap pelanggan memiliki value (terhadap produk atau jasa) yang berbeda. Jadi, untuk organisasi jasa, perlu identifikasi proses atau cara penyajian seperti apa yang tepat untuk pelanggan yang mana dan diberikan pada saat seperti apa. Agar proses identifikasi menjadi sederhana, para manajer, kiranya perlu melihat hierarki kebutuhan pelanggan (dikutip dari Noriaki Kano oleh Okran, 2000) yang terdiri dari: kebutuhan dasar, kebutuhan kinerja, dan delighters. Kebutuhan dasar mencakup features yang pelanggan anggap wajib ada (take for granted). Sebagai contoh, bila seorang membeli mobil baru, mobil itu harus memiliki empat ban. Bila keempat ban itu ada, atribut pemenuh kebutuhan dasar itu tidak akan membuat konsumen tersebut bangga (loved). Namun bila atribut tersebut tidak ada, ketidak hadiran pemenuh kebutuhan dasar akan membuat konsumen kecewa (anguish). Kebutuhan kinerja adalah item-item darima konsumen mengharapkan utilitas marjinal, untuk apa saja yang membuat konsumen mau membayar ekstra. Power windows, power door lock dan keyless remote entry adalah contoh-contoh features yang dapat memuaskan kebutuhan kinerja. Delighters adalah segala hal yang 
tidak diharapkan pelanggan tetapi hal-hal tersebut akan memuaskan pelanggan karena hal tersebut memuaskan apa yang pelanggan benar-benar anggap bernilai. Contoh dari hal-hal yang membuat pelanggan delight adalah bunga segar, atau penyemprot air, atau roti bakar hangat yang diberikan secara gratis kepada para pembeli mobil. Namun, merealisasikan delighters memerlukan biaya yang mahal, bahkan delapan (8) kali lebih mahal dari biaya merekrut pelanggan baru. Oleh karena itu pelaksanaan delighters perlu didukung dengan program loyalitas yang tepat dan diarahkan kepada pelanggan yang potensi loyalitasnya kuat.

\section{Garansi Jasa}

Garansi adalah salah satu cara untuk memperkuat daya tarik atau keyakinan dari suatu produk atau jasa dihadapan konsumen. Khusus untuk jasa, garansi merupakan salah satu solusi untuk mengatasi problem intangibilitas jasa. Garansi suatu jasa diberikan untuk meyakinkan konsumen bahwa jasa yang ditawarkan kepadanya memiliki atribut atau kualitas seperti yang dijanjikan.

Selama lebih dari satu dekade, organisasi jasa telah menggunakan garansi jasa untuk menarik dan membangun kesetiaan pelanggan. Garansi jasa adalah komitmen eksplisit kepada pelanggan berkaitan dengan semua atau sebagian proses jasa, biasanya termasuk kompensasi kepada pelanggan bila komitmen tersebut dilanggar (Kashyap, 200133). Secara umum garansi dibagi menjadi garansi tanpa syarat (guarantee) dan garansi bersyarat (warranty) Garansi tanpa syarat berlaku untuk kepuasan pelanggan terhadap keseluruhan proses jasa, sementara garansi bersyarat dikenakan untuk aspek jasa tertentu berlaku untuk satu atau beberapa elemen proses jasa saja.

${ }^{3}$ Dikutip dari Louis Fabien (2005)
Penerapan garansi menghadirkan tantangan yang tidak kecil, khususnya pada tataran implementasinya. Hal ini terungkap dalam penelitian Fabien (2005), meskipun komitmen garansi yang diberikan itu kurang kuat dan sangat subyektif, sementara kompensasi yang ditawarkannya pun kurang signifikan, tidak menutup kemungkinan bahwa meski untuk komitmen yang sederhana seperti itu pun, pada banyak kasus, memiliki kesulitan untuk mewujudkannya. Apalagi jika garansi yang ditawarkan itu sangat jelas dan kuat. Penganutan strategi garansi memungkinkan hadirnya gap yang lebar antara model garansi jasa yang "ideal" yang dijanjikan oleh pemberi jasa melalui strategi komunikasinya dengan apa yang diprkatekkan di lapangan sekarang ini. Meski demikian, kita percaya bahwa garansi jasa menawarkan sejumlah keuntungan. Masih menurut Fabien, gap itu muncul terutama dikarenakan kurangnya pemahaman para pemberi jasa tentang apa itu garansi jasa, apa manfaat dan kerugiannya.

\section{Komunikasi Terintegrasi}

Para pemasar jasa menghadapi tantangan berat ketika mereka harus mengkomunikasikan benefit intangibel dari jasa mereka kepada target sasaran (Matilla, $2000^{4}$ ). Sejumlah ahli menyarankan bahwa karena jasa itu intangibel, maka komunikasinya ditekankan pada aspek tangibel dari jasa yang ditawarkan. Ini demikian karena jasa baru dapat dirasakan atau dialami setelah jasa itu disajikan atau dikonsumsi. Karena itu, penting kiranya para konsumen mengenali tanda-tanda tangibel yang menyertai suatu jasa. Dengan tanda-tanda tangibel itu, para konsumen akan dapat memperkirakan derajat resiko yang akan diterimanya, juga dapat mengevaluasi kualitas (rasa atau pengalaman) dari jasa yang ditawarkan kepadanya. Menurut Berry

\footnotetext{
${ }^{4}$ Dikutip dari Carlson Grove et al (2002)
} 
(1986), secara sederhana dapat dikatakan bahwa para pemasar jasa harus membuat jasa itu lebih tangibel melalui strategi komunikasinya. Masalahnya adalah bagaimana caranya?

Ada yang menyarankan pesan yang disampaikan melalui periklanan harus menyajikan informasi yang faktual, menampilkan visualisasi dalam pikiran, atau membangun asosiasi dengan elemen-elemen fisikal. Saran lain menyangkut penekanan pada simbol-simbol dalam mengiklankan jasa dan/atau menggunakan iklan narasi sebagai alat untuk membuat pengalaman jasa lebih konkrit. Tujuan dari semua cara periklanan ini adalah untuk memfasilitasi pemahaman konsumen target tentang jasa yang ditawarkan sementara, pada waktu yang sama, menghindarkan potensi kegagalan komunikasi jasa yang menekankan abstraksi dan, karenanya, membingungkan. Padahal, jasa itu sendiri, secara inheren, sudah memiliki kekurangan dalam aspek kekonkritannya.

Tantangan lain yang dihadapi pemasar jasa adalah upaya "mengintegrasikan" berbagai bentuk bukti yang terkait dengan jasa dan penyajiannya untuk mengkompensasi sifat intangibilitas jasa. Komunikasi terintegrasi memiliki tujuan untuk menciptakan "kesan total" terhadap jasa dengan cara mengontrol alat-alat komunikasi terkait dengan jasa dan kinerjanya, termasuk isi dari periklanan jasanya.

\section{KEPUASAN DAN LOYALITAS PELANGGAN JASA}

Penulis berpendapat bahwa bagian ini sebaiknya didahului dengan perbedaan jasa dengan barang, implikasinya, dan bagiamana fungsi pemasaran diorganisasikan sehingga dapat memaksimumkan profit (Anonymous, 1989). Agar efektif, paparan di bawah ini akan disajikan dalam bentuk tanya jawab mencakup apa itu jasa, apa implikasi dari adanya sifat intangibilitas jasa, serta bagaimana sebaiknya memasarkan jasa.

a. Apa yang membentuk suatu jasa? Ada tiga atribut pokok yang membentuk suatu jasa. Pertama, jasa itu cenderung lebih intangibel (karena lebih merupakan tindakan, proses, atau prosedur) daripada barang; kedua, jasa cenderung diproduksi dan dikonsumsi lebih simultan daripada barang; dan ketiga, dalam produksi jasa porsi partisipasi aktif para pelanggan cenderung lebih besar daripada dalam produksi barang.

b. Apa implikasi dari ketiga atribut tersebut pada butir a terhadap cara jasa disajikan? Karena jasa itu bersifat intangibel, maka bagaimana cara jasa disajikan akan menentukan kualitas jasa itu dimata konsumen. Baik-tidaknya penyajian jasa seringkali bergantung kepada kemampuan karyawan. Karyawan menjadi aspek paling penting dan menentukan bagi pemasaran jasa yang memuaskan konsumen.

c. Bagaimana pemasaran seharusnya difungsikan sehingga bisa memaksimumkan profit? Fungsi pemasaran semestinya tidak hanya menjadi tanggungjawab bagian pemasaran, akan tetapi menjadi urusan semua orang dalam organisasi. Dengan kata lain, pemasaran juga perlu dilakukan ke dalam internal organisasi (internal marketing). Ini demikian karena, khsusunya untuk jasa, pemasaran tidak bisa dipisahkan dari aspek-aspek operasinya.

Simultanitas konsumsi dan produksi jasa sering menuntut konsumen untuk datang secara fisik ke "pabrik" jasa untuk secara tatap-muka berintekasi dengan karyawan. Konsekuensinya adalah para karyawan dituntut untuk tidak melakukan kesalahan sekecil apapun selama interaksi itu berlangsung. Dan ini hampir tidak mungkin. Kesalahan manusiawi amat sulit 
dihindarkan, dan bisa terjadi pada tiap tahapan proses manapun (di awal, tengah, atau akhir proses). Kekecewaan konsumen, barang tentu, menjadi pemicu yang cukup untuk mendorong konsumen pindah ke jasa yang ditawarkan produsen lain. Jadi, menawarkan dan menyajikan jasa yang kualitas (flowless = tanpa salah) adalah syarat minimal yang harus ada bila organisasi menginginkan pelanggannya puas, dan selanjutnya diharapkan akan loyal.

Kualitas jasa, sebagai media untuk menciptakan kepuasan, secara dominan bertumpu pada proses penciptaan dan penyajian jasa. Dengan kata lain, kualitas total sebuah jasa akan ditentukan oleh setiap tahapan proses atau penyajian jasa. Kemudian, karena jasa itu juga bersifat interaktif, maka kualitas jasa itu jauh lebih rentan daripada kualitas barang. Kualitas jasa, dan karenanya kepuasan terhadap jasa, sangat mudah cacat, meski oleh suatu kesalahan kecil yang terjadi di tahap paling akhir proses jasa. Ini berarti kualitas harus menjadi bagian fundamental dari struktur operasi; aliran aktifitas dan interaksi antara organisasi, konsumen, dan karyawan kontak; kerjasama antar karyawan; serta cara penyelesaian konflik yang muncul (Rodie et al., 1999).

Persepsi konsumen tentang kualitas jasa memiliki peran yang cukup signifikan bagi keberhasilan pemasaran jasa, karena persepsi berhubungan erat dengan level kepuasan yang dirasakan konsumen. Persepsi tentang kualitas juga berhubungan erat dengan fasilitas dan faktor manusia (Oswald et al., 1998). Semakin tinggi level persepsi konsumen terhadap kualitas suatu jasa, semakin tinggi kemungkinan konsumen kembali lagi dimasa datang atau merekomendasikan jasa tersebut kepada orang lain (Brown, 1997). Bagi konsumen sendiri, keputusannya untuk membeli lagi dimasa datang diambil berdasarkan pada persepsi tentang jasa yang diberikan dan bukannya didasarkan pada kualitas jasa aktual yang terukur secara obyektif. Jadi persepsi tentang kualitas jasa perlu dibangun, diperbaiki, dan dipertahankan. Implikasi umum dari perbaikan persepsi tentang kualitas jasa adalah: memperbaiki jasa aktual yang disediakan dan meningkatnya kualitas jasa yang diberikan.

Kepuasan adalah mediator dari hubungan antara kualitas dan loyalitas. Kualitas yang tinggi akan membuat konsumen puas. Kepuasan yang tinggi akan membuat konsumen melakukan pembelian ulang bahkan ada kemungkinan akan membuat konsumen loyal. Sejumlah ahli menyatakan bahwa dimensi kepuasan pada industri jasa berkaitan dengan harga, lokasi, kualitas jasa (faktor orang: staf jasa dan/atau konsumen lain), kualitas produk; juga mencakup waktu, usaha, serta biaya lain yang dikeluarkan untuk melakukan suatu pembelian, termasuk pencarian informasi internal maupun eksternal yang mendahului pembelian. Jika faktor-faktor penentu kepuasan ini ditransformasikan ke dalam dimensi-dimensi yang bisa diukur, maka penentu kepuasan menyeluruh dan pembelian ulang pada industri jasa adalah mencakup dimensi reliabilitas, respon, jaminan, empaty, dan tangibilitas. Para ahli tersebut menyadari bahwa meski demikian, karena jasa itu intangibel, konsumen masih sulit dalam mengukur kualitas dari jasa yang akan dibelinya. Kenyataan ini membuat faktor orang dan fasilitas fisik menjadi sangat dominan dalam upaya memuaskan konsumen. Alasannya adalah, disamping memiliki sifat intangible, jasa juga memiliki sifat interaktif, oleh karena itu maka para pelanggan sering menjadikan perilaku karyawan jasa dan fasilitas fisik sebagai acuan ketika menilai kualitas sebuah jasa. Konsekuensinya, level orientasi karyawan (dan design fasilitas, pen.) kepada konsumen dipertimbangkan sebagai kekuatan penting bagi keberhasilan ekonomis organisasi jasa 
(Bitner et al., 1990; Bove dan Johnson, 2000; Bowen dan Schneider, 1985; Sergeant dan Frenkel, 20005). Alasan lain adalah, karena jasa itu intangibel dan encounter nya yang modern, orang atau staf dan konsumen lain akan sangat menentukan (kualitas) interaksi interpersonal yang terjadi pada saat transaksi berlangsung (Skogland, 2004).

Implikasi lebih jauh dari sifat jasa yang intangibel (jasa itu proses, prosedur, atau tindakan) dan interaktif, maka setiap episode dimana seorang konsumen atau pengaruh kunci pembelian berinteraksi dengan organisasi jasa, produknya, karyawan, fasilitas, atau komunikasi mencerminkan suatu moment of truth atau encounter jasa, sebab setiap episode dapat menentukan kesan dan penilaian pelanggan terhadap organisasi (Benoy, 1996). Dengan demikian, dapat dikatakan bahwa kepuasan konsumen jasa adalah fungsi dari berbagai moment of truth dari berbagai pertukaran antara konsumen dengan organisasi jasa (Peltier et al. (1998).

Jika kepuasan memiliki hubungan dengan loyalitas, maka faktor-faktor pemuas suatu jasa dapat dijadikan elemen-elemen dari program loyalitas pelanggan. Berbeda dengan loyalitas terhadap barang, riset Skogland dan Judi (2004) menemukan bahwa hubungan antara kepuasan dan pembelian ulang (sebagai salah satu indikator loyalitas) pada sektor jasa (hotel) lemah. Temuan ini mengindikasikan bahwa para pemberi jasa perlu memiliki program loyalitas pelanggan, didasarkan pada aspek-aspek pemuas tersebut di atas, yang disusun dan diimplementasikan secara baik. Mengingat biaya untuk membangun loyalitas pelanggan itu mahal; sebagai contoh, Marriott mengeluarkan \$ 54 juta, dan Hyatt \$ 25 juta untuk program ini; keinginan konsumen selalu berubah/meningkat; perkembangan teknologi yang semakin canggih sehingga

${ }^{5}$ Dikutip dari Kay-wen Cheng (2006) bisa memproses sesuatu dengan lebih murah dan bagus; makin banyaknya pilihan yang kurang lebih sama yang tersedia bagi konsumen; maka pengusaha jasa perlu senantiasa mengevaluasi program loyalitas pelanggannya agar pelaksanaannya tetap mengarah kepada tujuan yang ingin dicapai: meningkatkan loyalitas pelanggan dan profit. Fokus dari program ini perlu diarahkan kepada aspek-aspek yang paling tinggi value nya dimata pelanggan. Dengan demikian, organisasi perlu senantiasa melakukan riset untuk mengidentifikasi aspek-aspek yang paling dianggap penting oleh pelanggan. Berikut adalah contoh program loyalitas pelanggan di dunia perhotelan. Para pelanggan memilih suatu hotel karena gedung dan fasilitas yang ditawarkan serta karyawannya. Oleh karena itu, para pengusaha hotel perlu memiliki program loyalitas pelanggan yang dikaitkan dengan upaya memperkuat sumberdaya manusia yang dimilikinya dan memperbaiki pengalaman para tamu melalui design operasi dan fasilitas yang dimilikinya.

Dari penjelasan di atas, switching barrier untuk pelanggan jasa nampaknya perlu mendapat perhatian lebih. Ada sejumlah alasan dari perlunya perhatian yang lebih serius dari manajemen terhadap switching barrier organisasi jasa. Pertama, karena sifat jasa intangibel dan interaktif (relatif face-to-face), proses produksi dan konsumsinya relatif simultan, sehingga memerlukan konsumen hadir di "pabrik" jasa, maka kegagalan pelayanan akan memberi kesan emosional yang mendalam dan, sangat mungkin, akan diingat dalam waktu yang lama. Sementara ahli menyatakan bahwa kegagalan pelayanan dapat merusak reputasi organisasi. Kedua, dari sisi pelanggan, pengalaman emosional negatif, selain menjadi pemicu perpindahan ke pesaing, dapat juga menjadi sumber modifikasi ekspektasinya dimasa datang sekaligus memperlebar dan meperdalam kriteria yang diguna- 
kan dalam pencarian (informasi dan organisasi) alternatif sebagai mekanisme untuk mengurangi resiko dari pembuatan keputusan pembelian dimasa datang. Dengan kata lain, pengalaman negatif membuat konsumen memiliki keterlibatan yang tinggi ketika membuat keputusan pembelian. Menurut Skogland et al. (2004), keterlibatan yang tinggi akan mengakibatkan loyalitas rendah dan sebaliknya.

Salah satu solusi untuk mencegah munculnya persoalan-persoalan seperti tersebut di atas, Lovelock (1992, 17) menyarankan digunakannya tiga fungsi manajemen -pemasaran, operasi, dan sumber daya manusia (disebut sebagai trinitas jasa)yang tidak bisa dipisahkan satu dengan lainnya ketika organisasi menciptakan dan menyajikan jasanya kepada para pelanggan. Oleh karena itu, khususnya bagi organisasi jasa yang padat karya dan tingkat kontak antara karyawan dan konsumennya tinggi, harus memiliki strategi pemasaran internal yang kuat, sehingga membuat semua karyawan atau operasi jasa berorientasi kepada konsumen. Alasannya adalah apabila diperlakukan dengan tepat, para karyawan akan memperlakukan konsumen secara tepat. Kalau demikian adanya berarti pemasaran internal dapat dijadikan basis bagi upaya penegakan switching barriers.

Patterson (2004) mengusulkan sejumlah barrier untuk mencegah pindahnya pelanggan, seperti membangun hubungan interpersonal yang kuat dengan pelanggan, memilih menawarkan jasa yang supplier alternatifnya sedikit, membebankan biayabiaya persiapan dan penalti finansial yang tinggi untuk perpindahan dini. Semuanya itu merepresentasikan biaya (psikologis dan ekonomis) yang dimaksudkan sebagai strategi unik untuk mencegah perpindahan pelanggan ke jasa lain. Arti praktisnya adalah apabila pada suatu kondisi tertentu seorang pelanggan merasa tidak puas terhadap jasa yang dikonsumsinya, ia akan tetap menerus- kan hubungan dengan organisasi jasa yang mengecewakannya itu karena biaya perpindahannya terlalu tinggi dan/atau karena telah memiliki hubungan personal yang baik. Program loyalitas atau hambatan perpindahan semacam ini sudah mulai umum diterapkan pada organisasi-organisasi perhotelan, penerbangan, departmen store, dan persewaan mobil.

Menurut Jones dan Sasser (1995), program loyalitas pelanggan memiliki potensi sebagai strategi untuk mempertahankan pelanggan kunci. Lebih dari itu, sementara kepuasan pelanggan menjadi elemen penting dalam mengamankan patronage, menurut Jones et al. (2000) hubungan dengan pelanggan yang kuat tersebut bisa jadi bergantung kepada switching barriers yang diterapkan dalam konteks pelayanan

\section{PENUTUP}

Keseluruhan paparan di atas membuat kita mengerti bahwa loyalitas merupakan salah satu fundamen sangat penting bagi eksistensi perusahaan, terutama dalam era yang sangat kompetitif seperti sekarang ini. Namun demikian, upaya mempertahankan pelanggan bukanlah perkara mudah. Ada banyak hal yang mempengaruhi, bahkan meniadakan loyalitas pelanggan pada organisasi. Oleh karena itu, manajemen bukan hanya dituntut untuk memahami aspek-aspek yang mendukung (customer value, consumer characteristics, customer satisfaction, customer experience, market factors) dan yang menghambat loyalitas (switching behaviors) saja, akan tetapi juga dituntut untuk tetap bersikap kritis terhadap hal-hal yang kelihatannya mendukung pembangunan loyalitas pelanggan (seperti customer delight), namun sebenarnya dapat membawa organisasi ke posisi yang melemahkan kemampuannya.

Lain dari itu, membangun loyalitas pelanggan secara efektif dan efisien juga perlu didukung oleh kemampuan organisasi 
dalam memilih segmen yang tepat; organisasi yang memadai. Membangun kepemilikan visi, misi, dan tujuan organisasi loyalitas pelanggan dimulai dari "pabrik".

yang jelas; serta kemampuan internal

\section{DAFTAR PUSTAKA}

Anonymous, (1989), Managing and marketing services. Incentive September; 163, 9; ABI/INFORM Global pg. 62.

Bansal, Harvir S., P. Gregory Irving, and Shirley F. Taylor (2004), A Three-Component Model of Customer Commitment to Service Providers. Academy of Marketing Science, Journal; Summer, 32, 3; ABI/INFORM Global.

Benoy, W. Joseph (1996), Marketing review: internal marketing builds service quality. Journal of Health Care Marketing; Spring; 16, 1; ABI/INFORM Global pg: 54.

Brown, Tom J (1997), Before the service encounter: referral variables influence patient perceptions of a specialist's service quality. Marketing Health Services; Spring; 17, 1; ABI/INFORM Global pg: 18

Budi Suharjo (2006), dikutip dari Dyah Hasto Palupi dalam: Para Kampiun Pencetak Loyalitas Pelanggan 2006. SWA. No. 06/XXII/23 Maret - 5 April.

Cheng, Kay-wen, (2006) What cunsumers need from restaurants: an empirical study on different classes of restaurants in taiwan and their customer service. Journal of American Academy of Business, Cambridge; March, 8, 1; ABI /INFORM Global.

Fabien, Louis (2005), Design and Implementation of a Service Guarantee, The Journal of Services Marketing; 19, 1. ABI/INFORM Global.

Fullerton, Gordon (2003), When does commitment lead to loyalty; Journal of Service Research. May; 5, 4. ABI/INFORM Global.

Grove, Carlson and Dorsch (2002), Addressing services' intangibility through integrated marketing communication: An Exploratory Study. Journal of Services Marketing. 18, 5; pp. 393-411.

Hennig-Thurou, Thorsten, (2004), Customer orientation of service employees: its impact on customer satisfaction, commitment, and retention. International Journal of Service Industry Management. 15, 5: ABI/INFORM Global.

Lovelock, Christopher; Jochen Wirtz; Hean Tat Keh; Xiongwen Lu. (2005), Services marketing, people, technology, strategy. $2^{\text {nd }}$ Edition, Pearson-Prentice Hall, Singapore.

Mariotti, John L. (1997), The shape shifters, continuous change for competitive advantage; Van Nostrand Reinhold; New York.

McKenzie, Roy (2000), The relationship-based enterprise, powering business success through customer relationship management; McGraw-Hill, Toronto. Pg. 27.

Mendelsohn, James D. (1998), Don't measure customer satisfaction - manage it; Marketing News; Oct. 26; 32, 22; ABI/INFORM Global pg. 42. 
Neal, William D. (2000), Letters To The Editor: For Most Customers, Loyalty Isn't An Attitude; Marketing News; Apr 10; 34, 8; ABI/INFORM Global pg. 7.

Okran, Marc R (2002), How To Convert '3's and '4's Into '5's; Marketing News; Oct 14, 36, 21; ABI/INFORM Global pg: 14.

Oswald, Sharon L; Douglas E Turner; Robin L Snipes; and Daniel Butler (1998), Quality determinant and hospital satisfaction: perception of the facility and and staff might be key influencing factors. Marketing Health Service. Spring; 18, 1; ABI/INFORM Global pg: 19.

Patterson, Paul G (2004), A contingency model of behavioral in a services context. European Journal of Marketing. 38, 9/10. ABI/INFORM Global.

Peltier, James W.; Thomas Boyt; John A Schibrowsky (1998), Relationship building: measueservice quality across health care encounters. Marketing Health Serfvice; Fall; 18, 3; ABI/INFORM Global pg: 16.

Rodie, Amy Risch; Louis G. Pol; Benkamin Crabtree; Helen McIlvain (1999), Assessing Quality. Marketing Health Services. Summer; 19, 2; ABI/INFORM Global pg: 16.

Sher, Shih-shue (2006), The application of quality function deployment (qfd) in product development. Journal of American Academy of Business, Cambridge; March, 8. 2; ABI/INFORM Global, pg: 292.

Skogland, Iselin; Judi A Siguaw (2004); Are Your Satisfied Customers Loyal?; Cornel Hotel and Restaurant Administration Quarterly; August, 45, 3; ABI/INFORM Global.

Sudarmadi (2005); Membangun Loyalitas Pelanggan; SWA 02/XXI/19 Januari - 2 Februari, hal. 48. 